\title{
Pengaruh Kepemimpinan Transformasional Terhadap Kinerja Karyawan Dengan Self-Efficacy Sebagai Variabel Mediasi pada Lembaga Perkreditan Desa (LPD) di Kecamatan Denpasar Timur
}

\author{
Putu Gede Denny Herlambang ${ }^{1 *}$, I Made Adi Suwandana ${ }^{2}$ \\ 1,2Fakultas Ekonomi dan Bisnis Universitas Ngurah Rai, Jalan Padma, Penatih, Kecamatan Denpasar
}

\section{A R T I C L E I N F O}

Article history:

Received 01 December 2019

Received in revised form 31 December 2019

Accepted 15 January 2020

Available online 26

February 2020

Kata Kunci:

Karyawan, Kepemimpinan

Transformasional, Self-

Efficacy

Keywords:

Employee Performance,

Transformational

Leadership, Self-Efficacy
A B S T R A K

Penelitian ini menguji secara empiris pengaruh kepemimpinan transformasional terhadap kinerja karyawan dengan self-efficacy sebagai variabel mediasi pada Lembaga Perkreditan Desa (LPD) di Kecamatan Denpasar Timur. Pengumpulan data dilakukan melalui penyebaran kuesioner kepada 93 orang karyawan dari 12 LPD di Kecamatan Denpasar Timur. Pengujian hipotesis dalam penelitian ini menggunakan analisis jalur (path analysis). Hasil penelitian menunjukkan kepemimpinan transformasional berpengaruh positif dan signifikan terhadap self-efficacy, self-efficacy berpengaruh positif dan signifikan terhadap kinerja karyawan, kepemimpinan transformasional berpengaruh positif dan signifikan terhadap kinerja karyawan dengan self-efficacy sebagai variabel mediasi pada Lembaga Perkreditan Desa (LPD) di Kecamatan Denpasar Timur.

\section{A B S T R A C T}

This study empirically examines the effect of transformational leadership on employee performance with self-efficacy as a mediating variable at the Lembaga Perkreditan Desa (LPD) in East Denpasar District. Data collection was carried out through the distribution of questionnaires to 93 employees from 12 LPDs in East Denpasar District. Testing the hypothesis in this study using path analysis. The results showed that transformational leadership had a positive and significant effect on self-efficacy, self-efficacy had a positive and significant effect on employee performance, transformational leadership had a positive and significant effect on employee performance with selfefficacy as a mediating variable at the Lembaga Perkreditan Desa (LPD) in East Denpasar District.

\footnotetext{
* Corresponding author.

E-mail addresses: Dennymm34@yahoo.com (Herlambang Putu Gede Denny)
} 


\section{Pendahuluan}

Sumber daya manusia merupakan kebutuhan utama untuk dapat menjalankan segala kegiatan yang ada di berbagai bidang organisasi dalam perusahaan. Salah satu faktor yang yang sangat memiliki peran untuk mempengaruhi perusahaan dalam mencapai target dalam berkompetisi adalah perusahaan diharapkan mempunyai sumber daya manusia yang kompeten, oleh karena itu manajemen sumber daya manusia memegang peranan yang penting untuk membantu perusahaan memperoleh sumber daya manusia yang tepat. Sumber daya yang dimaksud adalah pemimpin dan karyawan.

Perusahaan diharapkan mampu mengelola sumber daya manusia dengan baik agar dapat diandalkan dalam mencapai visi, misi dan target perusahaan, karena pengelolaan sumber daya manusia yang kurang baik dapat berdampak negatif terhadap terhambatnya tujuan perusahaan. Perusahaan diharapkan mendapatkan karyawan yang memiliki pengetahuan kemampuan serta keterampilan yang tinggi. Akan tetapi, keberhasilan perusahaan dalam mencapai tujuannya tidak hanya ditentukan oleh kualitas dari karyawan yang dimiliki perusahaan tersebut.Perusahaan diharapkan pula memiliki pemimpin yang mampu mendorong motivasi para karyawannya untuk dapat bekerja dengan baik dan optimal.

Gaya kepemimpinan yang diterapkan oleh seorang pemimpin di dalam suatu perusahaan memegang kunci utama dalam tercapainya lingkungan kerja yang baik. Dalam rangka peningkatan motivasi karyawan yang dilakukan oleh pemimpinakan berdampak pada peningkatan produktivitas dan kinerja karyawan, sehingga tujuan utama yang ingin dicapai oleh perusahaan dapat terwujud. Kepemimpinan yang efektif adalah pemimpin yang dapat menyesuaikan gaya kepemimpinannya sesuai dengan tingkat kematangan karyawan. Gordon dalam Nawawi (2006 : 63) mengungkapkan bahwa "kinerja merupakan suatu fungsi kemampuan pekerja dalam menerima tujuan pekerjaan, tingkat pencapaian tujuan dan interaksi antara tujuan serta kemampuan karyawan". Dari pendapat tersebut dapat disimpulkan bahwa karyawan memegang peranan penting dalam menjalankan aktifitas perusahaan, agar dapat tumbuh dan mempertahankan kelangsungan proses kerja dalam suatu perusahaan (Siswanto, 2017).

Dalam dunia yang diwarnai kompetisi global, khususnya dalam aspek bisnis dan ekonomi, perusahaan-perusahaan membutuhkan kinerja tinggi dari semua karyawannya. Kinerja adalah tingkat keberhasilan di dalam melaksanakan tugas serta kemampuan untuk mencapai tujuan yang telah ditetapkan (Darodjat, 2015:113). Gaya kepemimpinan adalah salah satu faktor fundamental yang mempengaruhi kinerja karyawan. Pemimpin yang memakai gaya kepemimpinan transformasional akan memotivasi bawahannya untuk menyelesaikan tugas dengan cara bawahannya masing-masing, jadi bawahan diajak untuk berpikir kreatif. Selain itu, bawahan akan diberikan tantangan yang terus meningkat kesulitannya (Bass et al., 2003).

Kepemimpinan transformasional tergantung dari kondisi psikologis seorang pemimpin dalam memotivasi karyawan untuk melakukan pekerjaan atau tugas yang lebih baik dari apa yang bawahannya inginkan dan bahkan lebih tinggi dari apa yang sudah diperkirakan sebelumnnya. Kondisi psikologis yang dimaksud dalam hal ini adalah keyakinan diri (self-efficacy) sebagai landasan kepribadian dalam mengarahkan bawahannya untuk bekerja (Riyadiningsih, 2013). Efektifnya kepemimpinan transformasional ditentukan oleh tinggi rendahnya self-efficacy seorang pemimpin dalam mentransformasi para bawahannya untuk dapat meningkatkan kesadaran tentang pentingnya suatu tugas sehingga akan mengakibatkan meningkatnya kinerja karyawan (Harjono, 2015).

Penelitian ini menguji secara empiris pengaruh kepemimpinan transformasional terhadap kinerja karyawan dengan self-efficacy sebagai variabel mediasi pada Lembaga Perkreditan Desa (LPD) di Kecamatan Denpasar Timur. Hal ini didasarkan pada pentingnya kinerja karyawan bagi kemajuan usaha LPD. Perkembangan Lembaga Perkreditan Desa (LPD) di Bali cukup pesat. Buktinya, dari hanya sebanyak 8 LPD pada tahun 1984 lalu, pada tahun 2016 jumlahnya sudah mencapai 1.443 LPD. Ribuan LPD ini tersebar di 9 kabupaten/ kota di Bali. Menariknya dari total 1.433 LPD ini, tidak semuanya berkembang dengan baik. Dari data yang didapatkan Pansus LPD, tercatat sebanyak 158 LPD (11,03 persen) di Bali yang justru dinyatakan bangkrut karena sudah tidak beroperasi lagi.

Kota Denpasar sebagai pusat perekonomian di Provinsi Bali memiliki 35 Desa Pakraman dan secara keseluruhan telah terdapat 35 LPD yang tersebar di setiap Kecamatan. Mempersempit wilayah penelitian, LPD Kecamatan Denpasar Timur dipilih sebagai lokasi penelitian disebabkan karena wilayah tersebut memiliki jumlah LPD terbanyak di Kota Denpasar yaitu 12 LPD. Penelitian ini bertujuan untuk mengetahui apakah pengaruh kepemimpinan transformasional berpengaruh terhadap self-efficacy, uUntuk mengetahui apakah pengaruh self-efficacy adalah positif dan signifikan terhadap kinerja karyawan, dan untuk mengetahui apakah pengaruh kepemimpinan transformasional adalah positif dan signifikan terhadap kinerja karyawan dengan self-efficacy sebagai variabel mediasi. 


\section{Metode}

Tempat penelitian ini dilakukan pada Lembaga Perkreditan Desa (LPD) di Kecamatan Denpasar Timur. Obyek dalam penelitian adalah bidang manajemen sumber daya manusia yaitu kinerja karyawan, kepemimpinan transformasional dan self-efficacy. Jumlah sampel penelitian ditentukan dengan metode sensus yaitu seluruh karyawan dari 12 LPD di Kecamatan Denpasar Timur. Data hasil pengumpulan data melalui penyebaran kuesioner, dikuantitatifkan dengan memberikan skor pada masing-masing jawaban responden. Skala pengukuran yang digunakan dalam penelitian ini adalah skala Likert dengan bobot: Sangat Tidak Setuju (STS) $=1$, Tidak Setuju $(T S)=2$, Cukup Setuju $(C S)=3$, Setuju $(S)=4$, dan Sangat Setuju (SS) $=5$. Validitas dan reliabilitas instrumen penelitian ditentukan terlebih dahulu sebelum data dianalisis. Pengujian hipotesis dalam penelitian ini menggunakan analisis jalur (path analysis). Analisis jalur (path analysis) merupakan perluasan dari analisis regresi linear berganda, atau analisis jalur adalah penggunaan analisis regresi untuk menaksir hubungan kausalitas antara variabel (model casual) yang telah ditetapkan sebelumnya berdasarkan teori (Ghozali, 2013:249).

\section{Hasil dan pembahasan}

1. Uji Validitas dan Reliabilitas Instrumen Penelitian

Hasil uji validitas dan reliabilitas instrumen penelitian menunjukkan seluruhnya adalah valid dan reliable sehingga seluruh instrumen penelitian dapat digunakan dalam analisis. Dikatakan valid karena koefisien korelasi product moment seluruhnya adalah lebih besar dari 0,30, hal ini berarti instrumen penelitian adalah sah yaitu pernyataan-pernyataan pada kuesioner mampu mengungkapkan apa yang diukur oleh kuesioner tersebut. Dikatakan reliable karena seluruh variabel mempunyai koefisien alpha Cronbach $>0,70$ sehingga instrumen penelitian adalah reliabel atau handal karena jawaban tiap responden dianggap konsisten atau stabil dari waktu ke waktu.

\section{Uji Asumsi Klasik}

Uji asumsi klasik dilakukan terlebih dahulu untuk mengetahui kelayakan penggunaan model regresi. Uji asumsi klasik yang digunakan terdiri dari: uji multikolinearitas, uji heteroskedastisitas dan uji normalitas.

Tabel 1. Hasil Uji Multikolinearitas

\begin{tabular}{clcc}
\hline \multirow{2}{*}{ No } & \multicolumn{2}{c}{ Variabel Bebas } & \multicolumn{2}{c}{ Collinearity Statistic } \\
& \multicolumn{1}{c}{ Tolerance } & VIF \\
\hline 1 & Kepemimpinan transformasional $\left(\mathrm{X}_{1}\right)$ & 0,594 & 1,684 \\
& Self-efficacy $\left(\mathrm{X}_{2}\right)$ & 0,594 & 1,684 \\
\hline
\end{tabular}

Sumber: Olah data SPSS

Berdasarkan Tabel 1 dapat disimpulkan bahwa tidak ada variabel independen yang memiliki nilai VIF lebih dari 10 dan nilai Tolerance kurang dari 0,10 menjelaskan tidak terjadi multikolinearitas atau tidak terjadi korelasi diantara variabel kepemimpinan transformasional dan self efficacy.

Tabel 2. Hasil Uji Heteroskedastisitas Dengan Uji Glejser

\begin{tabular}{lcc}
\hline \multicolumn{1}{c}{ Model } & $\mathrm{t}$ & Sig. \\
\hline Konstanta & 0,695 & 0,489 \\
Kepemimpinan transformasional $\left(\mathrm{X}_{1}\right)$ & $-0,074$ & 0,941 \\
Self-efficacy $\left(\mathrm{X}_{2}\right)$ & 0,859 & 0,393 \\
\hline
\end{tabular}

Hasil uji Glejser berdasarkan Tabel 2 diketahui bahwa variabel kepemimpinan transformasional diperoleh nilai probabilitas signifikansinya adalah $0,941>\alpha=0,05$. variabel self efficacy diperoleh nilai 
probabilitas signifikansinya adalah $0,393>\alpha=0,05$. Hasil ini menunjukkan bahwa koefisien regresi nilai absolut residual tidak signifikan, sehingga dapat dikatakan tidak terjadi heteroskedastisitas pada variabel kepemimpinan transformasional dan self efficacy.

Tabel 3. Hasil Uji Kolmogorov-Smirnov

\begin{tabular}{lc}
\hline & Unstandardized Residual \\
\hline $\mathrm{N}$ & 93 \\
Kolmogorov-Smirnof Z & 0,526 \\
Asymp. Sig (2-tailed) & 0,945 \\
\hline
\end{tabular}

Tabel 3 menunjukkan bahwa nilai Kolmogorov-Smirnof sebesar 0,529 dengan tingkat probabilitas sebesar 0,945. Nilai tingkat probabilitas atau Asymp. Sig (2-tailed) yang lebih besar dari level of significant 0,05 , berarti model regresi memenuhi asumsi normalitas atau data berdistribusi normal.

Berdasarkan hasil uji asumsi klasik maka diketahui pada persamaan regresi tidak terjadi gejala multikolinearitas, tidak terjadi gejala heteroskedastisitas dan distribusi datanya adalah normal sehingga model regresi bisa digunakan karena mendapatkan hasil prediksi yang baik atau bisa memberikan manfaat dengan benar.

Tabel 4. Hasil Analisis Pengaruh Kepemimpinan Transformasional $\left(\mathrm{X}_{1}\right)$ Terhadap Self-Efficacy $\left(\mathrm{X}_{2}\right)$

\begin{tabular}{|c|c|c|c|c|c|}
\hline \multirow{4}{*}{1} & \multirow{4}{*}{$\begin{array}{l}\text { Model } \\
\text { (constant) } \\
\text { X2 }\end{array}$} & \multicolumn{3}{|c|}{ Standardized Coeffcients } & \multirow[b]{2}{*}{ Sig } \\
\hline & & Beta & & $\mathrm{t}$ & \\
\hline & & & .723 & 4.600 & .000 \\
\hline & & & & 7.892 & .000 \\
\hline
\end{tabular}

Hasil analisis dinyatakan dalam bentuk persamaan regresi linier sederhana: $\mathrm{Y}=\mathrm{a}+\beta \rho \mathrm{x}_{2} \mathrm{X}_{2}+\mathrm{e}_{2}$. Berdasarkan Tabel 5 diperoleh persamaan regresi linier sederhana: $Y=10,227+0,723 \mathrm{X}_{2}$. Besarnya pengaruh diketahui dari nilai koefisien regresi self-efficacy terhadap kinerja karyawan $\left(\beta \rho \mathrm{yx}_{2}\right)$ yaitu sebesar 0,723. Hasil regresi menunjukan tingkat signifikansi adalah 0,000 di bawah 0,05 $(\rho=0,000<$ $0,05)$ sehingga hipotesis $\left(\mathrm{H}_{2}\right)$ diterima yaitu self-efficacy berpengaruh positif dan signifikan terhadap kinerja karyawan.

Hasil penelitian sesuai dengan pernyataan teori yaitu menurut Bandura (1997) dalam Baron dan Byrne (2010:183), self-efficacy adalah evaluasi seseorang terhadap kemampuan atau kompetensinya untuk melakukan sebuah tugas, mencapai tujuan atau mengatasi hambatan. Disebutkan juga self-efficacy adalah keyakinan seseorang akan kemampuan atau kompetensinya atas kinerja tugas yang diberikan, mencapai tujuan atau mengatasi sebuah hambatan.

Hasil penelitian mempertegas temuan secara empirik dari beberapa hasil penelitian sebelumnya. Hasil penelitian Indrawati (2014), Lunenburg (2011), Meier (2011) dan Iroegbu (2015) yang menunjukkan bahwa terdapat pengaruh yang positif dan signifikan dari self-efficacy terhadap kinerja karyawan dengan dimediasi oleh self-efficacy.

Tabel 5. Hasil Analisis Pengaruh Self-Efficacy $\left(\mathrm{X}_{2}\right)$ Terhadap Kinerja Karyawan (Y)

\begin{tabular}{|c|c|c|c|c|c|}
\hline & & Stanc & & & \\
\hline \multirow{3}{*}{1} & Model & Beta & & $\mathrm{t}$ & Sig \\
\hline & (constant) & & .723 & 7.226 & .000 \\
\hline & $\mathrm{X} 2$ & & & 9.998 & .000 \\
\hline
\end{tabular}

Hasil analisis dinyatakan dalam bentuk persamaan regresi linier sederhana : $\mathrm{Y}=\mathrm{a}+\beta \rho \mathrm{x}_{2} \mathrm{X}_{2}+\mathrm{e}_{2}$. Berdasarkan Tabel 5 diperoleh persamaan regresi linier sederhana: $Y=10,227+0,723 X_{2}$. Besarnya pengaruh diketahui dari nilai koefisien regresi self-efficacy terhadap kinerja karyawan $\left(\beta \rho \mathrm{yx}_{2}\right)$ yaitu sebesar 0,723. Hasil regresi menunjukan tingkat signifikansi adalah 0,000 di bawah 0,05 $(\rho=0,000<$ $0,05)$ sehingga hipotesis $\left(\mathrm{H}_{2}\right)$ diterima yaitu self-efficacy berpengaruh positif dan signifikan terhadap kinerja karyawan. 
Hasil penelitian sesuai dengan pernyataan teori yaitu menurut Bandura (1997) dalam Baron dan Byrne (2010:183), self-efficacy adalah evaluasi seseorang terhadap kemampuan atau kompetensinya untuk melakukan sebuah tugas, mencapai tujuan atau mengatasi hambatan. Disebutkan juga self-efficacy adalah keyakinan seseorang akan kemampuan atau kompetensinya atas kinerja tugas yang diberikan, mencapai tujuan atau mengatasi sebuah hambatan.

Hasil penelitian mempertegas temuan secara empirik dari beberapa hasil penelitian sebelumnya. Hasil penelitian Indrawati (2014), Lunenburg (2011), Meier (2011) dan Iroegbu (2015) yang menunjukkan bahwa terdapat pengaruh yang positif dan signifikan dari self-efficacy terhadap kinerja karyawan.

Tabel 6. Hasil Analisis Pengaruh Kepemimpinan Transformasional $\left(\mathrm{X}_{1}\right)$ Terhadap Kinerja Karyawan $(\mathrm{Y})$ dengan Self-Efficacy $\left(\mathrm{X}_{2}\right)$ Sebagai Variabel Mediasi

\begin{tabular}{|c|c|c|c|}
\hline Model & $\begin{array}{l}\text { Standardized Coeffcients } \\
\text { Beta }\end{array}$ & $\mathrm{t}$ & Sig \\
\hline $1 \quad$ (constant) & & 5.342 & .000 \\
\hline $\mathrm{X} 1$ & .434 & 5.249 & .000 \\
\hline X2 & .447 & 9.998 & .000 \\
\hline
\end{tabular}

Metode analisis data yang digunakan yaitu regresi linier berganda yang mengandung interaksi antara variabel independen. Mengukur pengaruh kepemimpinan transformasional terhadap kinerja karyawan dengan self-efficacy sebagai variabel mediasi digunakan dua persamaan:

$\begin{array}{llc}\mathrm{X}_{2} & = & \mathrm{a}+\beta \rho \mathrm{x}_{2} \mathrm{x}_{1} \mathrm{X}_{1}+\mathrm{e}_{1} \\ \mathrm{X}_{2} & = & 5,606+0,637 \mathrm{X}_{1} \\ \mathrm{Y}= & \mathrm{a}+\beta \rho y \mathrm{x}_{1} \mathrm{X}_{1}+\beta \rho \mathrm{yx}_{2} \mathrm{X}_{2}+\mathrm{e}_{2} \\ \mathrm{Y}= & 7,292+0,434 \mathrm{X}_{1}+0,447 \mathrm{X}_{2}\end{array}$

Besarnya pengaruh tidak langsung, yaitu pengaruh kepemimpinan transformasional terhadap kinerja karyawan dengan self-efficacy sebagai variabel mediasi, dihitung dengan cara:

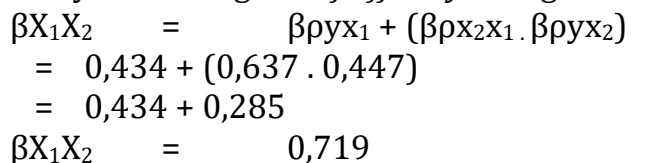

Hasil analisis menunjukkan bahwa $\beta \mathrm{X}_{1} \mathrm{X}_{2}=0,719$ adalah lebih besar daripada $\beta \rho \mathrm{x}_{2} \mathrm{x}_{1}=0,637$ dengan tingkat signifikansi adalah 0,000 di bawah 0,05 $(\rho=0,000<0,05)$ sehingga hipotesis $\left(\mathrm{H}_{3}\right)$ diterima yaitu: kepemimpinan transformasional berpengaruh positif dan signifikan terhadap kinerja karyawan dengan self-efficacy sebagai variabel mediasi.

Hasil penelitian sesuai dengan pernyataan teori yaitu Faktor self-efficacy menentukan keberhasilan kinerja pada setiap perubahan organisasi, dengan kata lain bahwa kemampuan diri merupakan bagian yang sangat signifikan di dalam meningkatkan kinerja perusahaan (Setiaji, 2013). Self-efficacy adalah variabel motivasi yang mempengaruhi individu terhadap kegiatan, pencapaian tujuan, ketekunan dan kinerja dalam berbagai konteks (Chan, 2012).

Hasil penelitian mempertegas temuan secara empirik dari beberapa hasil penelitian sebelumnya. Hasil penelitian Cavazotte (2013), Barling (2010) dan Harjono (2015) menunjukkan bahwa self-efficacy sebagai variabel mediasi memberikan efek positif dan signifikan bagi pengaruh kepemimpinan transformasional terhadap peningkatan kinerja karyawan.

\section{Simpulan dan saran}

Berdasarkan hasil analisis data dan pembahasan diperoleh simpulan hasil penelitian pada Lembaga Perkreditan Desa (LPD) di Kecamatan Denpasar Timur. Kepemimpinan transformasional berpengaruh positif dan signifikan terhadap self-efficacy. Self-efficacy berpengaruh positif dan signifikan terhadap kinerja karyawan. Kepemimpinan transformasional berpengaruh positif dan signifikan terhadap kinerja karyawan dengan self-efficacy sebagai variabel mediasi. 


\section{Daftar Rujukan}

Aggarwal, Jyoti and Venkat R. Krishnan. 2012. Impact of Transformational Leadership on Follower's Selfefficacy: Moderating Role of Follower's Impression Management. Journal of Great Lakes Institute of Management Chennai, pp. 1-17.

Barling, Julian. 2010. Transformational Leadership Elevating Employees to Affect The Bottom Line. Journal of Queen Executive Development Centre, pp. 1-4.

Baron, Robert A. dan Donn Byrne. 2010. Psikologi Sosial. Jakarta: Erlangga.

Bass, Bernard M., Bruce J. Avolio, Dong I. Jung and Yair Berson. 2003. "Predicting Unit Performance by Assessing Transformational and Transactional Leadership. Journal of Applied Psychology, 88 (2), pp. 207-218.

Beverborg, Arnoud Oude Groote. 2015. Towards Sustaining Levels of Reflective Learning: How Do Transformational Leadership, Task Interdependence, and Self-efficacy Shape Teacher Learning in Schools?. Journal of Societies, 5, pp. 187-219.

Cavazotte, Flávia. 2013. Transformational Leaders and Work Performance: The Mediating Roles of Identification and Self-efficacy. Journal BAR Rio de Janeiro, 10 (4), pp. 490-512.

Chan, Simon C. H. 2012. The Psychological Mechanisms of Transformational Leadership to Followers' Performance. Journal Department of Management and Marketing, The Hong Kong Polytechnic University, pp.1-18.

Darodjat, Tubagus Achmad, 2015. Konsep-Konsep Dasar Manajemen Personalia Masa Kini. Bandung: PT. Refika Aditama.

Fadzilah, Ari. 2006. Analisis Pengaruh Pemberdayaan Karyawan dan Self of Efficacy Terhadap Kinerja Karyawan Bagian Penjualan (Studi Kasus pada PT Sinar Sosro Wilayah Pemasaran Semarang). Jurnal Studi Manajemen dan Organisasi, 3 (1), hal. 12-27.

Fitzgerald, Susan and Nicola S. Schutte. 2010. Increasing Transformational Leadership Through Enhancing Self-efficacy. Journal of Management Development, 29 (5), pp. 495-505.

Ghozali, Imam. 2013. Aplikasi Analisis Multivariat dengan Program SPSS. Semarang: Badan Penerbit Universitas Diponegoro.

Ghufron, Nur dan Rini Risnawita, 2012. Teori-teori Psikologi. Yogyakarta: Aruzz Media.

Harjono, Gerald Joseph. 2015. Pengaruh Kepemimpinan Transformasional dan Self-efficacy Terhadap Kinerja Pegawai PT Air Manado, Jurnal EMBA, 3 (3), hal. 1040-1049.

Indrawati, Yeti. 2014. Pengaruh Self Esteem, Self-efficacy Dan Kepuasan Kerja Terhadap Kinerja Karyawan (Studi Kasus Perawat RS Siloam Manado). Jurnal Riset Bisnis dan Manajemen, 2 (4), hal. 12-24.

Iroegbu, Manasseh N. . 2015. Self-efficacy and Work Performance: A Theoretical Framework of Albert Bandura's Model, Review of Findings, Implications and Directions for Future Research. Psychology and Behavioral Sciences, 4 (4), pp. 170-173.

Lunenburg, Fred C. 2011. Self-efficacy in the Workplace: Implications for Motivation and Performance. International Journal of Management, Business, and Administration, 14 (1), pp. 1-6.

Meier, Kenneth J.. 2011. Isopraxis Leadership: Self-efficacy, Managerial Strategy, and Organizational Performance. Department of Political Science Texas A and M University, pp. 1-40.

Mensah, Abigail Opoku. 2013. The Influence of Employees' Self-efficacy on Their Quality of Work Life: The Case of Cape Coast, Ghana. International Journal of Business and Social Science, 4 (2), pp. 195-205. 
Mesterova, Jana. 2015. Relationship between Self-efficacy, Transformational Leadership and Leader Effectiveness. Journal of Advanced Management Science, 3 (2), pp. 109-122.

Riyadiningsih, Hening. 2013. Peran Kondisi Psikologis dan Karakteristik Pribadi Dalam Pengembangan Kepemimpinan Efektif: Sebuah Tinjauan Konseptual. Jurnal Program Studi Manajemen Unwiku, hal. $1-8$.

Setiaji. 2013. Pengaruh Kepemimpinan Transformasional, Kemampuan Diri dan Kepuasan Kerja Terhadap Kinerja Pegawai Dinas Pendidikan Kabupaten Klaten Derajat. Jurnal Program Studi Magister Manajemen Program Pasca Sarjana Universitas Muhammadiyah Surakarta, hal. 1-14.

Siswanto, Rendyka Dio . 2017. Pengaruh Gaya Kepemimpinan Terhadap Kinerja Karyawan (Studi Pada Karyawan Divisi Human Resources Management Compensation And Benefits Pt Freeport Indonesia) . Jurnal Administrasi Bisnis (JAB)|Vol. 42 No.1 Januari 2017

Sugiyono. 2016. Metode Penelitian Bisnis. Bandung: Alfabeta.

Yukl, Garry A. 2012. Kepemimpinan Dalam Organisasi. Jakarta: Indeks. 